\title{
A new condensation product for zinc plating from non-cyanide alkaline bath
}

\author{
Y ARTHOBA NAIK and T V VENKATESHA* \\ Department of Studies in Chemistry, Kuvempu University, Shankaraghatta 577 451, India
}

\begin{abstract}
Zinc electroplating from non-cyanide alkaline solution is carried out in the presence of condensation product formed between DL-alanine (DLA) and glutaraldehyde. The bath constituents and bath variables are optimized through standard Hull cell experiments. The current efficiency and the throwing power are measured. High shift of potential towards more cathodic direction was observed in presence of addition agents. Corrosion resistance test reveals good protection of base metal by zinc coating obtained from the developed electrolyte. SEM photomicrographs show fine-grained deposit in the presence of condensation product. IR spectrum of the scraped deposit shows the inclusion of the condensation product in the deposit during plating. The consumption of brightener in the lab-scale is $6 \mathrm{mLL}^{-1}$ for 1000 amp-hour.
\end{abstract}

Keywords. Alkaline bath; electroplating; Hull cell studies; non-cyanide bath; zinc plating.

\section{Introduction}

Electrodeposition of zinc on steel is carried out to protect steel from corrosion. The sacrificial protection afforded by zinc is due to its position in the electrochemical series with respect to iron. The reason for the pre-eminence of zinc in the world of electrodeposition can be attributed to its relative ease of deposition and better corrosion resistance. To get good bright zinc deposition certain organic compounds are being used in the bath solution (Rosenberg and Holland 1991; Tang 1993; Bapu et al 1998). Development of these brighteners for non-cyanide alkaline solution is continuously taking place even though few efficient commercial brighteners are available (Blount 1970; Arthoba Naik et al 2000a,b). It is evident from the available literature that single addition agent generally does not produce good deposit over a wide current density range. In order to get good deposit, two or more addition agents are required (Hayashida 1972; Hoyer 1973; Rushmore 1977; Suzuki and Susa 1996). The presence of many addition agents poses problem in determining their consumption during plating. Also some of the addition agents cause pollution problem and health hazard.

In the present work, efforts have been made to develop non-cyanide alkaline bath solution containing single brightener. In the present work, various amines and aldehydes are subjected to condensation reaction by adopting standard procedures (Moris and Boyd 1973). The obtained products are subjected to Hull cell experiment. Among these, condensation product formed between DL-alanine (DLA) and glutaraldehyde (GTD) acts as a very good brightener and it is easily soluble in water.

*Author for correspondence (arthoba@yahoo.co.in)

\section{Experimental}

The chemicals used were of AR grade and the solutions were prepared with distilled water. Zinc plate of $99.99 \%$ purity was used as anode. Mild steel plates (AISI-1079) of standard Hull cell size were polished mechanically and degreased by dipping in boiling trichloroethylene. Finally these were dipped in $10 \% \mathrm{HCl}$ followed by electrocleaning. The standard Hull cell of $267 \mathrm{ml}$ capacity was used to optimize the bath constituents and bath parameters (Parthasaradhy 1989). The zinc electroplated steel plates were subjected to water wash and given bright dip in $1 \%$ nitric acid for 2-3 s. The nature and appearance of zinc plating was carefully studied and recorded through the Hull cell codes (figure 1a).

The optimized solution was taken in a rectangular methacrylate cell of 2.51 capacity. Polished, degreased and electrocleaned cathodes of $3 \times 4 \mathrm{~cm}^{2}$ were used for plating. These plated steel cathodes were used to test different metallurgical properties. Experiments were done in triplicate. Standard experimental procedures (Parthasaradhy 1989) were adopted for the measurement of metallurgical properties of the deposit such as ductility, hardness, adherence etc. In all the above studies the average thickness of the deposit was $25 \mu \mathrm{m}$. The coating thickness was measured by using $\beta$-ray back scattering gauge (Permascope ESD9, West Gut-ESD9 KB4, $220 \times$ 50-60 Hz, Germany) and BNF jet methods.

For polarization studies, a three-compartment cell was used. The zinc metal plate was used as anode and steel plate as cathode. The cathode potential was measured galvanostatically, with respect to saturated calomel electrode at different current densities. Current efficiency and throwing power measurements were carried out by using Haring and Blum cell. The current distribution ratio be- 
tween anode and cathode was $1: 5$ for throwing power measurement.

IR spectrum of the scratched deposit was taken to study the inclusion of addition agents. SEM photomicrographs were taken to ascertain the nature of the deposit in presence of addition agents. For determining consumption of brightener a rectangular 2.51 methacrylate cell was used.

\section{Results and discussion}

\subsection{Hull cell studies}

3.1a Effect of condensation product: Bath solution containing zinc sulphate, sodium hydroxide, CTAB and EDTA gave coarse dull deposit between the current density range of 0.5 and $3.5 \mathrm{Adm}^{-2}$ at $1 \mathrm{~A}$ cell current. To improve the nature of the deposit, condensation product formed between DL-alanine (AR grade, s.d. Fine Chemicals, Mumbai, India) and glutaraldehyde (AR grade, s.d. Fine Chemicals, Mumbai, India), was added to the bath solution. Condensation product was prepared by mixing $5 \mathrm{~g}$ of DL-alanine and $20 \mathrm{~mL}$ of glutaraldehyde $(25 \%$ aqueous solution) in distilled water and refluxing the resulting aqueous solution for $3 \mathrm{~h}$ at $343 \mathrm{~K}$ (Moris and Boyd 1973). The resulting dark red product was diluted to $100 \mathrm{~mL}$ with distilled water and a known amount of this solution was added to the bath. At low concentration of the condensation product the deposit was semibright between the current density range of 1.0 and $3.0 \mathrm{Adm}^{-2}$. At low current density, dull and at high current density, burnt deposits were obtained. With increase in the concentration of condensation product, nature of the deposit improved and at a concentration of $4 \mathrm{mLL}^{-1}$ the Hull cell

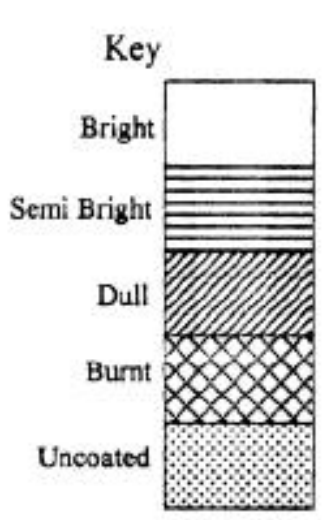

(a)

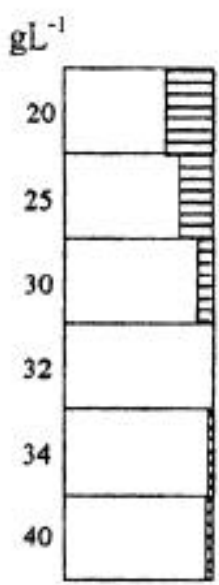

(e)

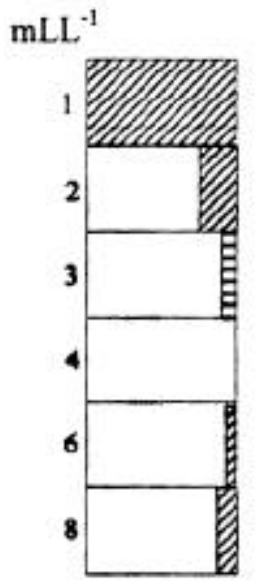

(b)

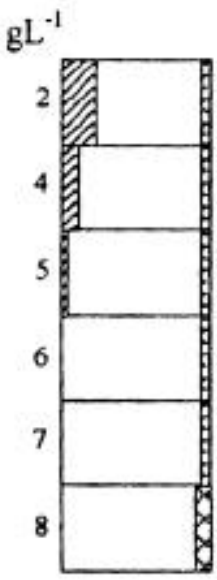

(c)

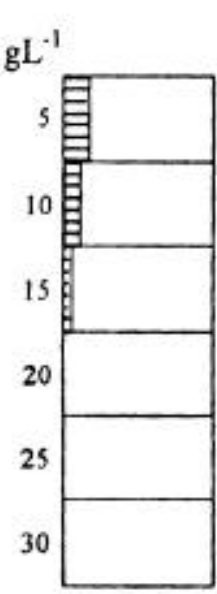

(d)

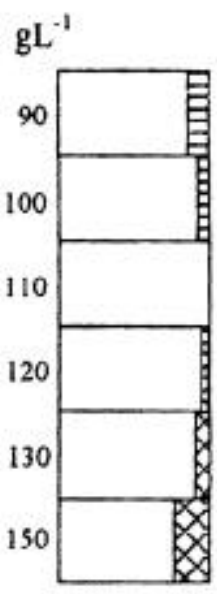

(f)
$\operatorname{Temp}(K)$

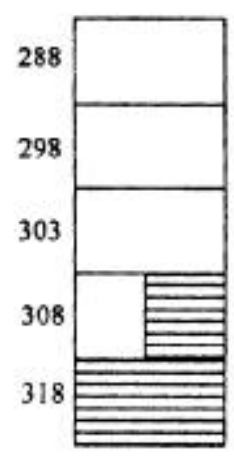

(g)
Current(A)

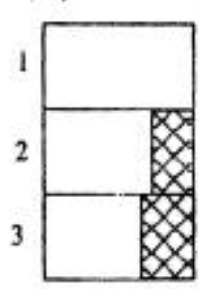

(h)

Figure 1. Hull cell figures: (a) key, (b) effect of condensation product, (c) effect of CTAB, (d) effect of EDTA, (e) effect of $\mathrm{ZnSO}_{4}$, (f) effect of $\mathrm{NaOH}$, (g) effect of temperature and (h) effect of cell current. 
panels were bright between the current density range of 0.1 and $3.5 \mathrm{Adm}^{-2}$. Further increase in the concentration of the condensation product gave dull deposit in the high current density region. Based on the above observation the concentration of the condensation product was kept at $40 \mathrm{mLL}^{-1}$ as optimum. The Hull cell patterns are shown in figure $1 b$.

3.1b Effect of CTAB: The concentration of CTAB was varied from $1-12 \mathrm{gL}^{-1}$, keeping the concentration of sodium hydroxide at $100 \mathrm{gL}^{-1}$, zinc sulphate at $30 \mathrm{gL}^{-1}$ and condensation product at $20 \mathrm{mLL}^{-1}$. At low concentration of CTAB the nature of deposit was semibright in the current density range $0.5-3.5 \mathrm{Adm}^{-2}$. Above $3.5 \mathrm{Adm}^{-2}$, burnt deposit was observed. With increase in the concentration of CTAB from 1 to $6 \mathrm{gL}^{-1}$, burnt deposit area was reduced and at a concentration of $6 \mathrm{gL}^{-1}$, bright deposit was obtained in the current density range $0 \cdot 2-3.8 \mathrm{Adm}^{-2}$ at $1 \mathrm{~A}$ cell current. With increase in the concentration, no change in the nature of deposit was observed. Therefore, the concentration of CTAB was fixed at $6 \mathrm{gL}^{-1}$ as optimum in the bath solution (figure 1c).

3.1c Effect of EDTA: Further, the concentration of EDTA was varied from 5-50 $\mathrm{gL}^{-1}$. At low concentration of EDTA $\left(<20 \mathrm{gL}^{-1}\right)$, the deposit was bright in the current density range $0 \cdot 2-3.8 \mathrm{Adm}^{-2}$. At a concentration of $20 \mathrm{gL}^{-1}$ in the bath solution, bright deposit was obtained over the entire current density region $\left(0 \cdot 1-4 \cdot 0 \mathrm{Adm}^{-2}\right.$ at $1 \mathrm{~A}$ cell current). Above $20 \mathrm{gL}^{-1}$ of EDTA, no improvement in the nature of deposit was observed. Therefore, the concentration of EDTA was fixed at $20 \mathrm{gL}^{-1}$ as optimum. The effect of EDTA on Hull cell cathodes at 1A cell current is as shown in figure $1 \mathrm{~d}$.

3.1d Effect of zinc sulphate: To know the effect of zinc metal ion concentration, the zinc sulphate concentration was varied from $10-40 \mathrm{gL}^{-1}$. At low concentration, the bright deposit was observed in the current density range between 0.5 and $3.0 \mathrm{Adm}^{-2}$. In the low current density region, dull and at high current density region, burnt deposits were obtained. With increase in the concentration of zinc sulphate, the brightness range was extended to high and low current density regions. At a concentration of $35 \mathrm{gL}^{-1}$, satisfactory bright deposit was obtained in the current density range of $0 \cdot 1-4 \mathrm{Adm}^{-2}$ at $1 \mathrm{~A}$ cell current. With increase in the concentration of zinc sulphate no improvement in the nature of deposit was observed. The concentration of zinc sulphate was fixed at $35 \mathrm{gL}^{-1}$ as optimum and Hull cell patterns are as shown in figure 1e.

3.1e Effect of $\mathrm{NaOH}$ : The concentration of sodium hydroxide was varied from $80-120 \mathrm{gL}^{-1}$. At low concentration $\left(<100 \mathrm{gL}^{-1}\right)$, the bath solution was turbid and the nature of deposit was patchy and dull. With increase in the concentration, the turbidity found to disappear and at a concentration of $100 \mathrm{gL}^{-1}$ the bath solution was clear. At a concentration of $110 \mathrm{gL}^{-1}$ the nature of deposit was full bright in the current density range 0.1-4.0 $\mathrm{Adm}^{-2}$. Further increase in the concentration of sodium hydroxide resulted in the black deposit in the high current density region. Therefore, the concentration of sodium hydroxide was fixed at $110 \mathrm{gL}^{-1}$ as optimum in the bath solution. The Hull cell patterns showing the effect of sodium hydroxide are shown in figure $1 \mathrm{f}$.

3.1f Effect of temperature: The effect of temperature on electrodeposition was investigated by conducting Hull cell experiments at controlled temperature. The temperature of the bath solution was varied from 293-323 K. At lower temperatures $(<303 \mathrm{~K})$, the deposit was bright in the current density range between $0 \cdot 1$ and $4 \mathrm{Adm}^{-2}$ at $1 \mathrm{~A}$ cell current. Above $308 \mathrm{~K}$ the entire Hull cell cathode was covered with dull deposit. So the optimum temperature range was 298-303 K. Hull cell panels showing the effect of temperature are given in figure $1 \mathrm{~g}$.

3.1g Effect of cell current: The Hull cell experiments were carried out at different cell currents $(1-3 \mathrm{~A})$ for 5 min using optimized bath solution. It was found that at a cell current of $1 \mathrm{~A}$, the deposit was bright in the current density range $0 \cdot 1-4 \cdot 0 \mathrm{Adm}^{-2}$. At a cell current of $2 \mathrm{~A}$, the deposit was bright in the current density range $0 \cdot 1-$ $5.5 \mathrm{Adm}^{-2}$. At a cell current of $3 \mathrm{~A}$ the deposit was bright over the current density range $0 \cdot 1-5 \cdot 6 \mathrm{Adm}^{-2}$. These observations revealed that the bath produced the bright deposit in the current density range $0 \cdot 1-5 \cdot 6 \mathrm{Adm}^{-2}$. The Hull cell patterns are as shown in figure $1 \mathrm{~h}$.

\subsection{Current efficiency and throwing power}

The current efficiency and throwing power were measured under different plating conditions. The effect of temperature, EDTA, CTAB, zinc and condensation product on current efficiency and throwing power were investigated at a current density of $3 \mathrm{Adm}^{-2}$ and the values are given in table $2 \mathrm{a}$. The current efficiency was found to vary from $58-65 \%$ and the throwing power from $40-49 \%$.

The current efficiency and throwing power were measured at different current densities using optimum bath composition. The current efficiency varied from 47-65\% and throwing power from $44-49 \%$. The variation of cur-

Table 1. Basic bath composition and operating conditions.

\begin{tabular}{lrl}
\hline Bath composition & Range & \multicolumn{1}{c}{ Operating conditions } \\
\hline $\mathrm{ZnSO} \cdot 7 \mathrm{H}_{2} \mathrm{O}\left(\mathrm{gL}^{-1}\right)$ & 25 & Anode : Zinc metal $(99 \cdot 99 \%)$ \\
$\mathrm{NaOH}\left(\mathrm{gL}^{-1}\right)$ & 100 & Cathode : Mild steel \\
$\mathrm{CTAB}\left(\mathrm{gL}^{-1}\right)$ & 3 & Temperature : 293-303 K \\
EDTA $\left(\mathrm{gL}^{-1}\right)$ & 10 & Cell current : $1 \mathrm{~A}$ \\
\hline
\end{tabular}


rent efficiency and throwing power with current density is given in table $2 \mathrm{~b}$.

\subsection{Polarization study}

The potential of steel cathode was measured galvanostatically with respect to saturated calomel electrode, at different current densities. Cathodic polarization was measured using the bath solution with and without addition agents. The variation of cathode potential with current density is shown in figure 2. At any given current density, the cathode potential became more negative in presence of CTAB and EDTA. This shift was still higher in presence of all the addition agents.

Table 2a. Current efficiency and throwing power at $3 \mathrm{Adm}^{-2}$ current density.

\begin{tabular}{lccc}
\hline Bath constituents/parameters & Range & $\begin{array}{c}\text { Current efficiency } \\
(\%)\end{array}$ & $\begin{array}{c}\text { Throwing power } \\
(\%)\end{array}$ \\
\hline $\mathrm{ZnSO}_{4} \cdot 7 \mathrm{H}_{2} \mathrm{O}\left(\mathrm{gL}^{-1}\right)$ & $20-40$ & $58-65$ & $45-49$ \\
$\mathrm{NaOH}\left(\mathrm{gL}^{-1}\right)$ & $90-150$ & $60-65$ & $46-49$ \\
$\mathrm{CTAB}\left(\mathrm{gL}^{-1}\right)$ & $4-8$ & $63-65$ & $44-49$ \\
$\mathrm{EDTA}\left(\mathrm{gL}^{-1}\right)$ & $10-30$ & $62-65$ & $40-49$ \\
Condensation product & $2-12$ & $62-65$ & $41-49$ \\
$(\mathrm{DLA}-\mathrm{GTD})\left(\mathrm{mLL}^{-1}\right)$ & $293-323$ & $60-65$ & $42-49$ \\
Temperature $(\mathrm{K})$ & &
\end{tabular}

Table 2b. Current efficiency and throwing power at different current densities.

\begin{tabular}{lcc}
\hline $\begin{array}{l}\text { Current density } \\
\left(\mathrm{Adm}^{-2}\right)\end{array}$ & $\begin{array}{c}\text { Current efficiency } \\
(\%)\end{array}$ & $\begin{array}{c}\text { Throwing power } \\
(\%)\end{array}$ \\
\hline $1 \cdot 0$ & 58 & 44 \\
$2 \cdot 0$ & 65 & 48 \\
$3 \cdot 0$ & 65 & 49 \\
$4 \cdot 0$ & 59 & 49 \\
$5 \cdot 0$ & 47 & 48 \\
\hline
\end{tabular}

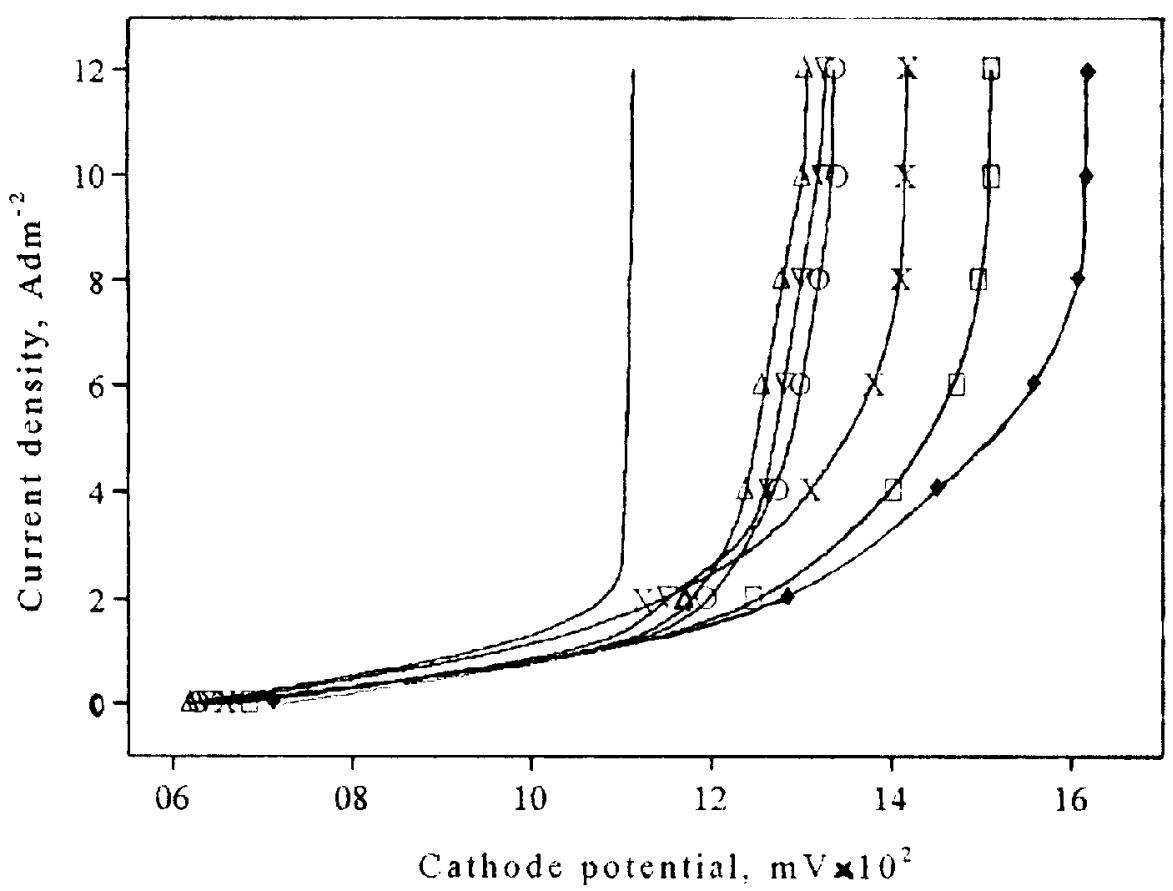

Figure 2. Effect of addition agents on cathodic potential $\left(-, \mathrm{ZnSO}_{4}+\mathrm{NaOH}(\mathrm{BB}) ; \nabla\right.$, $\mathrm{BB}+\mathrm{EDTA} ; \quad \Delta, \quad \mathrm{BB}+\mathrm{CTAB} ; \quad \mathrm{O}, \quad \mathrm{BB}+\mathrm{EDTA}+\mathrm{CTAB} ; \quad \times, \quad \mathrm{BB}+$ DL-alanine; $\square$, $\mathrm{BB}+$ glutaraldehyde; $\bullet \mathrm{BB}+\mathrm{EDTA}+\mathrm{CTAB}+$ DL-alanine-glutaraldehyde). 
In IR spectrum of the scraped deposit the absorption peak near $1600 \mathrm{~cm}^{-1}$ (stretching frequency of $-\mathrm{C}=\mathrm{N}-$ bond) indicates and confirms the inclusion of the condensation product in the deposit (figure 3 ).

\subsection{Corrosion resistance}

Mild steel panels of $2 \times 2 \mathrm{~cm}^{2}$ area were polished, degreased and treated with $10 \%$ hydrochloric acid followed by water wash. These plates were plated with zinc in optimum plating bath at different current densities. In presence of addition agents, it was found that the deposits were pore-free above a thickness of $5 \mu \mathrm{m}$ as indicated by ferroxyl test. In absence of addition agents, the coating was highly porous even at a thickness of $8 \mu \mathrm{m}$.

The corrosion resistance of zinc plated steel plates was tested by salt spray method (ASTM B-117). Mild steel plates $\left(5 \times 5 \mathrm{~cm}^{2}\right)$ were coated with zinc from an optimum bath solution. These plates were given bright dip in $1 \%$ nitric acid followed by chromate passivation. Before subjecting to the salt spray test, the plates were kept in a clean and dry atmosphere for $24 \mathrm{~h}$. Even after $120 \mathrm{~h}$ of salt spray test no white rust was observed on the specimens. This indicated good corrosion resistance of the deposit.

\subsection{Metallurgical properties}

An important property of an electrodeposit is its adhesion to the base metal. Usually, zinc deposits on mild steel have good adhesion. To measure adherence the zinc de- posits of $15 \mu \mathrm{m}$ thickness were obtained under optimum conditions of plating bath on mild steel plates $(1 \times$ $10 \mathrm{~cm}^{2}$ ). These plated specimens were subjected to bend test through $90^{\circ}$ and finally through $180^{\circ}$. Even after $180^{\circ}$ bending no crack or peel off was observed in the deposit. This reveals good adhesion of zinc deposit to the substrate. The more useful method for measuring microhardness involves making an indentation with an indenter of specified geometry under a specified load. The length of indentation is expressed in vickers hardness number (VHN). Zinc was electroplated on mild steel panels up to a thickness of $25 \mu \mathrm{m}$ and a load of $50 \mathrm{~g}$ was employed. The microhardness of zinc was found to be 130 .

SEM photomicrographs of zinc deposit obtained from the basic bath solution with and without addition agents are shown in figure 4 . These indicate that the basic bath produced only coarse-grained deposits. The grain size was refined further in presence of addition agents. Finegrained smooth deposit was obtained from the bath solution containing an optimum concentration of all the addition agents.

\subsection{Consumption of brightener}

To know the amount of addition agents consumed in the bath, 2.51 of bath solution was taken and plating was carried out at different current densities. The total number of coulombs passed to the bath solution was recorded at the time when the bath just started to give semibright deposit. The bath solution after use was subjected to Hull cell test by adding different amounts of condensation

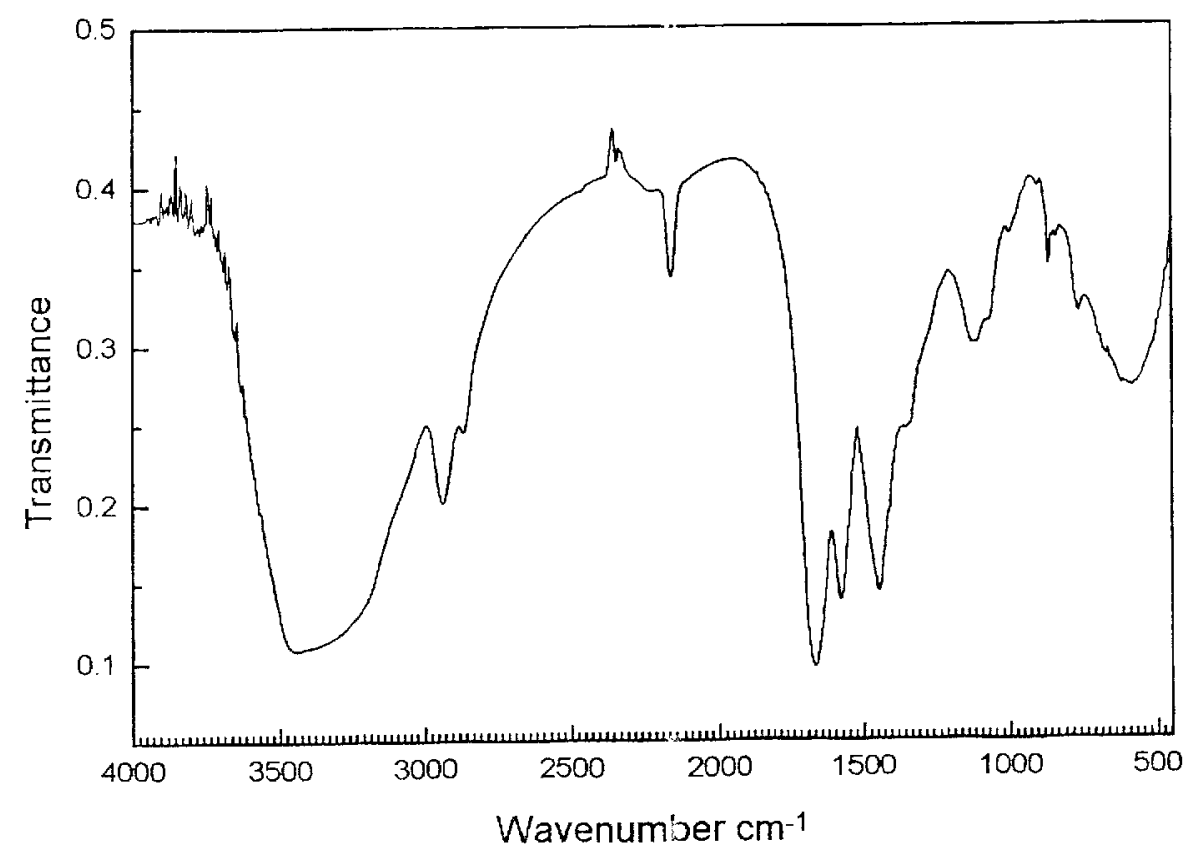

Figure 3. IR spectrum of the scraped zinc deposit. 
product. The concentration of condensation product, at which once again bright deposit was obtained, was determined. The amount of condensation product consumed for 1000 amps-h was $2 \mathrm{mLL}^{-1}$.

\subsection{Pilot plant study}

The commercial applicability of the developed bath was
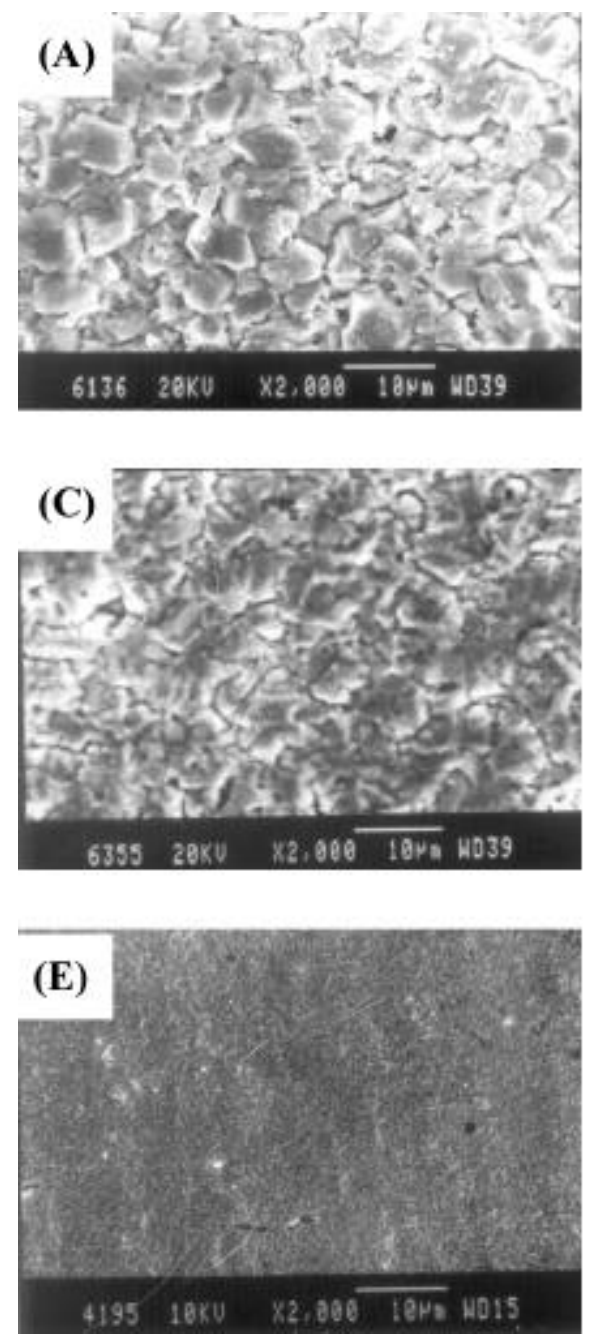

explored by performing the plating experiments in a vat bath of 251 capacity. The bath solution with optimum concentration of bath constituents was prepared. Steel components of different sizes and shapes (plates, rods, nuts, bolts, small pipes, clamps, etc) were degreased, electrocleaned and given acid dip followed by water wash. These treated components were rigged by copper wire and connected to the negative terminal of d.c. source. Electroplating was carried out at different current densi-
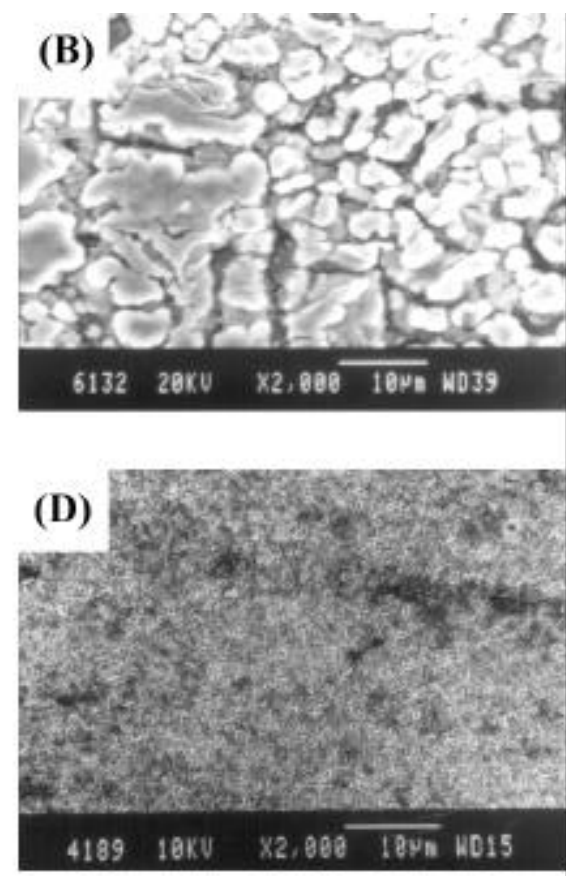

Figure 4. SEM photomicrographs of the deposits obtained at $3 \mathrm{Adm}^{-2}$ in the presence and absence of addition agents at $298 \mathrm{~K}$ : (A) basic bath (BB), (B) BB + CTAB, (C) BB + EDTA, (D) BB + CTAB + EDTA, (E) optimized bath and (F) passivated deposit.

Table 3. Optimum bath composition and operating conditions.

\begin{tabular}{lrl}
\hline Bath composition & Range & \multicolumn{1}{c}{ Operating conditions } \\
\hline $\mathrm{ZnSO}_{4} \cdot 7 \mathrm{H}_{2} \mathrm{O}\left(\mathrm{gL}^{-1}\right)$ & 35 & Anode : Zinc metal $(99.99 \%)$ \\
$\mathrm{NaOH}\left(\mathrm{gL}^{-1}\right)$ & 110 & Cathode : Mild steel \\
$\mathrm{CTAB}\left(\mathrm{gL}^{-1}\right)$ & 6 & Temperature : 293-303 K \\
EDTA $\left(\mathrm{gL}^{-1}\right)$ & 20 & Bright current \\
Condensation product & & density range : 0.1-5.6 Adm \\
(DLA-GTD) (mLL & Agitation : Air \\
\hline
\end{tabular}


ties with and without agitation of the bath solution. The components after deposition were removed from the plating vat and subjected to bright dip and passivation. The passivated articles were subjected to corrosion resistance test in salt spray chamber. Adhesion of the deposit to the substrate was good as it was confirmed by bend test and heat test methods. The components of irregular shapes plated under stirred and unstirred condition showed no rust at the recesses even after $96 \mathrm{~h}$ of salt spray test. This indicated the ability of the bath to produce uniform deposit on the components of irregular shape. The decrease in metal ion concentration for $1000 \mathrm{amps}-\mathrm{h}$ was determined and it was $1.5 \mathrm{~g} \mathrm{~L}^{-1}$. This was replenished by adding an equivalent amount of zinc sulphate to the bath solution.

\section{Conclusions}

The developed bath produces good deposit over the current density range of $0 \cdot 1-5 \cdot 6 \mathrm{Adm}^{-2}$. The optimized bath composition is shown in table 3 . The throwing power is reasonably good. The brightener can be easily synthesized. The addition agents are non-toxic, easily soluble in water and hence require no treatment of the effluent. The deposit is pore-free and corrosion resistant. The bath could be easily commercialized.

\section{References}

Arthoba Naik Y, Venkatesha T V and Vasudeva Nayak P 2000a B. Electrochem. 16481

Arthoba Naik Y, Venkatesha T V and Vasudeva Nayak P 2000b J. Electrochem. Soc. India 49170

Arthoba Naik Y, Venkatesha T V and Vasudeva Nayak P 2001 Indian J. Chem. Technol. 8390

Bapu G N K, Rames G Devaraj and Ayyapparaj J 1998 J. Solid State Electrochem. 348

Blount E A 1970 Electroplat. Metal Finish. 2327

Hayashida 1972 Japan Patent 7,216,521

Hoyer 1973 German Patent 2,247,875

Moris R T and Boyd R N 1973 Organic chemistry (New Delhi: Prentice-Hall of India Pvt Ltd) 2nd ed., p. 633

Parthasaradhy N V 1989 Practical electroplating handbook (New Jersey: Prentice Hall Inc) 1st ed., p. 283

Rosenberg W E and Holland F H 1991 Plat. Surf. Finish 7851

Rushmore 1977 German Patent 2,643,898

Suzuki Isamu and Susa Hideo 1996 Jpn Kokai Tokkyo Koho JP 08209393 A2

Tang Chun-hua 1993 Diandu Yu Tushi 1233 